\title{
Influence of Different Hydration and Dehydration Techniques on Quality and Yield in fenugreek (Trigonella foenumgraecum $L$.)
}

\author{
Nalla Bharath Reddy ${ }^{1 *}$, B. Prudvi Raj ${ }^{1}$, Bineeta M. Bara ${ }^{1}$, \\ K. Jahnavi ${ }^{2}$ and G. Abdul Wajid ${ }^{2}$
}

${ }^{1}$ Department of Genetics and Plant Breeding, Naini Agricultural Institute, Sam Higginbottom University of Agriculture, Technology and Sciences, Prayagraj, U. P., India

${ }^{2}$ State Institute for Management of Agriculture, Department of Agriculture, Govt. of Uttar Pradesh, India

*Corresponding author

\section{A B S T R A C T}

\begin{tabular}{l} 
Key w or d s \\
Hydration, \\
Dehydration \\
Quality, Yield, \\
Fenugreek \\
Article Info \\
\hline $\begin{array}{l}\text { Accepted: } \\
\text { 04 November } 2020 \\
\text { Available Online: } \\
10 \text { December } 2020\end{array}$ \\
\hline
\end{tabular}

In order to determine the influence of different seed hydration and dehydration techniques on growth, yield and seed quality parameters in fenugreek, an experiment was conducted in year 2019at the Field Experimentation Centre and Post Graduate Laboratory, Department of Genetics and Plant Breeding, Sam Higginbottom University of Agriculture, Technology and Sciences, Prayagraj (U.P) in RBD (Randomized Block Design) and CRD (Completely Randomized Block Design) having three and four replications respectively. The results showed that the effect of seed treatments was significant on all quantitative and qualitative characters except field emergence and seedling dry weight at $5 \%$ level of significance. Mean comparison showed that treatment $\mathrm{T}_{7}\left(\mathrm{CaCl}_{2}\right)(3 \%)$ were identified as a best treatment with maximum field emergence $93.04 \%$, plant height $(74.90 \mathrm{~cm})$, number of branches per plant (2.10), early days to 50 percent flowering (34.91), number of pods per plant (15.20), number of seeds per pod (8.17), pod fresh weight (1.93 g), pod dry weight $(0.91 \mathrm{~g})$, seed yield per plant $(93.04 \mathrm{~g})$, biological yield $(530.30 \mathrm{~g})$ and harvest index $(2.94$ g) followed by $\mathrm{T}_{5}\left(\mathrm{KNO}_{3}\right)(3 \%)$ when compared with control $\left(\mathrm{T}_{0}\right)$. In qualitative parameters $\mathrm{T}_{7}\left(\mathrm{CaCl}_{2}\right)(3 \%)$ showed better performance followed by $\mathrm{T}_{5}\left(\mathrm{KNO}_{3}\right)(3 \%)$ when compared with control $\left(\mathrm{T}_{0}\right)$.

\section{Introduction}

Fenugreek belongs to Leguminacea family; it was named, Trigonella, from Latin language that means "little triangle" due to its yellowish-white triangular flowers (Flammang et al., 2004). Fenugreek (Trigonella foenum-graecum L.) is one of the oldest medicinal plants from Fabaceae family originated in central Asia 4000 BC (Altuntas et al., 2005).

Its description and benefits had been reported in the Ebers Papyrus (one of the oldest maintained medicinal document) earlier in 1500BC in Egypt (Betty, 2008). It is being commercially grown in India, Pakistan, Afghanistan, Iran, Nepal, Egypt, France, 
Spain, Turkey, Morocco, North Africa, Middle East and Argentina (Flammang et al., 2004; Altuntas et al., 2005).

The country produces more than two million tons of spices annually. India is the largest producer and exporter in the world. It is cultivated across the country though production is concentrated in Madhya Pradesh, Rajasthan and Gujarat. In India it is cultivated in an area of 149330 ha with 213340 tons production (Spice Board of India-2017-18).

It is an important short duration (90- 120 days) crop of high nutritive valve having high nitrogen fixing ability and is grown during Rabi, kharif as well as summer seasons in arid and semi-arid regions of India. Fenugreek is cultivated mostly in India, Pakistan, USA, Italy, Morocco, Germany, and Spain (Punia et al., 2009).

Fenugreek seeds contain substantial amount of fiber (Montgomery, 2009; Meghwal and Goswami, 2012), phospholipids, glycolipids, oleic acid, linolenic acid, linoleic acid (Suliemanet al., 2000; Chatterjee et al., 2010), choline, vitamin A, B1, B2, C, nicotinic acid, niacin (Leela and Shafeekh, 2008), and many other functional elements. Despite of its exceptional nutritional and medicinal value, only a few studies have been done for its genetic enhancements and development of production agronomy.

Fenugreek is an annual legume, diploid $(2 \mathrm{n}=16)$ plant (Ahmad et al., 1999) with no aneuploidy (Petropoulos, 2002; Trease and Evans, 2002; Flammang et al., 2004). Morphologically, it is anerect, aromatic annual closely resembling large clover. The stem is long cylindrical (30 to $60 \mathrm{~cm}$ long) and pinkish in color; whereas its roots are massive finger like structures (Basu, 2006; Mehrafarin et al., 2011; Moradikor and
Moradi, 2013). Fenugreek has pinnate, trifoliate, long stalked compound leaves having toothed, lanceolate, stipules triangular, obovate to obancelolate leaflets (Srinivasan, 2006; Basu, 2006). It blooms with white to yellowish white, axillary and sessile flowers that are hermaphrodite and insect pollinated. Flowers have 5 petals referred asbanner, wing and keel. The ovary is deep green and glaucous while the pollen grains are oval tocircular in shape (Basu, 2006; Montgomery et al., 2009; Mehrafarin et al., 2011). Fenugreek flower produces brownish to yellowish brown $\sim 15 \mathrm{~cm}$ long 2-8 pods. Each pod contains 10-20seeds per pod; seeds are small ( $\sim 5 \mathrm{~mm}$ long), hard, smooth, dull yellow to brownish yellow incolor (Altuntas, 2005; Moradikor and Moradi, 2013).

Hydration and dehydration in its traditional sense, soaking or drying of seeds in chemicals/water before sowing, has been the experience of farmers in India in an attempt to improve crop stand establishment but the practice was without the knowledge of the safe limit of soaking duration (Harris, 1996).

The advantage of seed hydration and dehydration in reducing the germination time and improving emergence uniformity is well established under laboratory conditions.

\section{Materials and Methods}

The Research study was conducted at experimental research field, Department of Genetics and Plant Breeding, Naini Agriculture Institute, Sam Higginbottom University of Agriculture, Technology and Sciences, Prayagraj during kharif-2019. The experiment was carried out at Field Experimentation Centre of the Department of Genetics and Plant Breeding, Sam Higginbottom University of Agriculture, Technology \& Sciences. Prayagraj (UP) during Kharif-2019 to influence of different 
hydration and dehydration techniques on quality and yield infenugreek (Trigonella foenumgraecum $\mathrm{L}$.)

The experiment comprised of thirteen treatments in Randomized Block Design (RBD) with three replications for field experiment and Completely Randomized Design (CRD) with four replications for laboratory experiment. The data was collected on five randomly selected plants from each plot and measurement of different observations was recorded.

The treatments were represented as T0 (Control), T1 (Distilled water), T2 (KCl@ 1\%), T3 (KCl @ 3\%), T4 (KNO3 @ 1\%), T5 $\left(\mathrm{KNO}_{3} @ 3 \%\right), \quad \mathrm{T} 6 \quad\left(\mathrm{CaCl}_{2} @ 1 \%\right), \mathrm{T} 7$ $\left(\mathrm{CaCl}_{2} @ 3 \%\right), \mathrm{T} 8(\mathrm{NaCl} @ 1 \%), \mathrm{T} 9(\mathrm{NaCl} @$ 3\%), T10 (Salicylic Acid (200 ppm), T11(Gibberellic Acid (GA3) (100 ppm), T12 (Indole Acetic Acid (IAA) (100 ppm).

\section{Results and Discussion}

The treatment $\mathrm{T}_{7}\left(\mathrm{CaCl}_{2}\right)$ (3\%) showed better performance among all treatments in terms of field emergence $93.04 \%$, plant height $(74.90$ $\mathrm{cm}$ ), number of branches per plant (2.10), days to 50 percent flowering (34.91), number of pods per plant (15.20), number of seeds per pod (8.17), pod fresh weight (1.93 g), pod dry weight $(0.91 \mathrm{~g})$, seed yield per plant $(93.04$ $\mathrm{g})$, biological yield (530.30 g) and harvest index $(2.94 \mathrm{~g})$. and it was followed by the treatment $\mathrm{T}_{5}\left(\mathrm{KNO}_{3}\right)(3 \%)$ was second best after $\mathrm{T}_{7}\left(\mathrm{CaCl}_{2}\right)(3 \%)$ among all treatments in terms of all parameters viz: field emergence $87.38 \%$, plant height $(70.46 \mathrm{~cm})$, number of branches per plant (2.00), days to 50 percent flowering (35.77), number of pods per plant (13.46), number of seeds per pod (7.60), pod fresh weight $(1.92 \mathrm{~g})$, pod dry weight $(0.71$ g), seed yield per plant (87.38 g), biological yield $(486.86 \mathrm{~g})$ and harvest index $(2.40 \mathrm{~g})$ (Table 1 and 2).

Table.1 Mean performance of growth and yield parameters in fenugreek

\begin{tabular}{|c|c|c|c|c|c|c|c|c|c|c|c|c|}
\hline \multicolumn{2}{|c|}{ Treatments } & $\begin{array}{c}\text { Field } \\
\text { emergence }\end{array}$ & $\begin{array}{c}\text { Plant } \\
\text { height } \\
\text { (cm) }\end{array}$ & $\begin{array}{c}\text { Day to } 50 \\
\% \\
\text { flowering }\end{array}$ & $\begin{array}{c}\text { Number of } \\
\text { primary } \\
\text { branches / } \\
\text { plant }\end{array}$ & $\begin{array}{c}\text { Number } \\
\text { of pod / } \\
\text { plant }\end{array}$ & $\begin{array}{l}\text { Number } \\
\text { of seed / } \\
\text { pod }\end{array}$ & $\begin{array}{l}\text { Pod } \\
\text { weight } \\
\text { fresh } \\
(\mathrm{g})\end{array}$ & $\begin{array}{l}\text { Pod } \\
\text { weight } \\
\text { Dry } \\
\text { (g) }\end{array}$ & $\begin{array}{l}\text { Seed } \\
\text { t yield / } \\
\text { plant } \\
\text { (g) }\end{array}$ & $\begin{array}{l}\text { Biological } \\
\text { yield (g) }\end{array}$ & $\begin{array}{l}\text { Harvest } \\
\text { Index } \\
\text { (g) }\end{array}$ \\
\hline \multicolumn{2}{|l|}{$\mathbf{T}_{\mathbf{0}}$} & 76.10 & 52.63 & 39.66 & 1.20 & 8.00 & 5.52 & 1.56 & 0.21 & 78.21 & 276.03 & 1.23 \\
\hline \multicolumn{2}{|l|}{$T_{1}$} & 81.79 & 60.96 & 39.00 & 1.30 & 9.53 & 5.82 & 1.83 & 0.63 & 80.07 & 427.56 & 1.74 \\
\hline \multicolumn{2}{|l|}{$\mathbf{T}_{2}$} & 85.16 & 59.90 & 38.00 & 1.76 & 12.33 & 6.57 & 1.83 & 0.66 & 79.19 & 349.46 & 1.93 \\
\hline \multicolumn{2}{|l|}{$\mathbf{T}_{3}$} & 81.69 & 65.03 & 37.00 & 1.80 & 11.73 & 6.21 & 1.81 & 0.52 & 81.16 & 416.36 & 1.91 \\
\hline \multicolumn{2}{|l|}{$\mathbf{T}_{4}$} & 79.90 & 61.20 & 39.00 & 1.40 & 12.93 & 6.10 & 1.83 & 0.51 & 83.29 & 322.46 & 1.54 \\
\hline \multicolumn{2}{|l|}{$\mathbf{T}_{5}$} & 87.38 & 70.46 & 35.77 & 2.00 & 13.46 & 7.60 & 1.92 & 0.71 & 87.38 & 486.86 & 2.40 \\
\hline \multicolumn{2}{|l|}{$T_{6}$} & 83.61 & 57.73 & 37.33 & 1.46 & 13.40 & 6.43 & 1.78 & 0.56 & 82.31 & 373.93 & 2.00 \\
\hline \multicolumn{2}{|l|}{$\mathbf{T}_{7}$} & 93.04 & 74.90 & 34.91 & 2.10 & 15.20 & 8.17 & 1.93 & 0.91 & 93.04 & 530.30 & 2.94 \\
\hline \multicolumn{2}{|l|}{$\mathbf{T}_{8}$} & 83.51 & 60.06 & 38.66 & 1.50 & 11.20 & 7.54 & 1.86 & 0.63 & 80.54 & 377.93 & 2.01 \\
\hline \multicolumn{2}{|l|}{$T_{9}$} & 79.00 & 55.76 & 36.33 & 1.66 & 10.33 & 7.20 & 1.83 & 0.50 & 81.61 & 371.23 & 1.94 \\
\hline \multicolumn{2}{|l|}{$T_{10}$} & 85.74 & 62.30 & 39.33 & 1.34 & 9.52 & 7.44 & 1.71 & 0.47 & 82.53 & 330.93 & 1.60 \\
\hline \multicolumn{2}{|l|}{$\mathbf{T}_{11}$} & 83.29 & 64.00 & 36.21 & 1.70 & 9.92 & 6.91 & 1.82 & 0.42 & 79.34 & 288.70 & 1.76 \\
\hline \multicolumn{2}{|l|}{$\mathbf{T}_{12}$} & 81.47 & 55.63 & 37.33 & 1.39 & 10.42 & 6.09 & 1.79 & 0.70 & 82.84 & 334.70 & 1.90 \\
\hline \multicolumn{2}{|c|}{ Grand Mean } & 83.20 & 61.58 & 37.57 & 1.58 & 11.38 & 6.73 & 1.80 & 0.57 & 82.42 & 375.88 & 1.91 \\
\hline \multicolumn{2}{|c|}{ S E } & 1.08 & 5.93 & 4.20 & 1.81 & 1.42 & 0.22 & 1.42 & 0.23 & 0.31 & 104.15 & 1.81 \\
\hline \multicolumn{2}{|l|}{ CD 5\% } & NS & 2.18 & 1.69 & 0.33 & 38.00 & 1.30 & 0.07 & 0.02 & 4.03 & 36.51 & 1.26 \\
\hline \multicolumn{2}{|l|}{ CV } & 6.90 & 2.02 & 2.58 & 11.82 & 10.32 & 11.31 & 2.46 & 2.20 & 2.83 & 51.64 & 1.75 \\
\hline \multirow[t]{2}{*}{ Range } & Max & 93.04 & 74.9 & 39.66 & 2.1 & 15.2 & 8.17 & 1.93 & 0.91 & 93.04 & 530.3 & 2.94 \\
\hline & Min & 76.1 & 52.63 & 34.91 & 1.2 & 8 & 5.52 & 1.56 & 0.21 & 78.21 & 276.03 & 1.23 \\
\hline
\end{tabular}


Table.2 Mean performance of seed quality parameters in fenugreek

\begin{tabular}{|c|c|c|c|c|c|c|c|c|}
\hline Treatments & $\begin{array}{c}\text { Germination } \\
(\%)\end{array}$ & $\begin{array}{c}\text { Root } \\
\text { length } \\
(\mathrm{cm})\end{array}$ & $\begin{array}{c}\text { Shoot } \\
\text { length } \\
(\mathrm{cm})\end{array}$ & $\begin{array}{l}\text { Seedling } \\
\text { length } \\
(\mathrm{cm})\end{array}$ & $\begin{array}{l}\text { Seedling } \\
\text { fresh } \\
\text { weight } \\
\text { (gm) }\end{array}$ & $\begin{array}{c}\text { Seedling } \\
\text { dry } \\
\text { weight } \\
\text { (gm) }\end{array}$ & $\begin{array}{l}\text { Vigour } \\
\text { index I }\end{array}$ & $\begin{array}{c}\text { Vigour } \\
\text { index } \\
\text { II }\end{array}$ \\
\hline $\mathbf{T}_{0}$ & 57.12 & 1.1 & 2.12 & 3.24 & 1.001 & 0.001 & 188.92 & 0.057 \\
\hline $\mathbf{T}_{1}$ & 57.14 & 1.41 & 2.41 & 3.82 & 1.009 & 0.009 & 218.19 & 0.51 \\
\hline $\mathbf{T}_{2}$ & 58.13 & 1.13 & 2.25 & 3.25 & 1.011 & 0.011 & 230.84 & 0.63 \\
\hline $\mathbf{T}_{3}$ & 65.15 & 1.22 & 2.5 & 4.02 & 1.001 & 0.001 & 218.67 & 0.06 \\
\hline $\mathbf{T}_{4}$ & 63.26 & 1.52 & 2.14 & 3.24 & 1.002 & 0.002 & 204.99 & 0.12 \\
\hline $\mathbf{T}_{5}$ & 65.76 & 1.52 & 2.52 & 4.04 & 1.018 & 0.018 & 261.9 & 1.17 \\
\hline$T_{6}$ & 62.11 & 1.13 & 2.21 & 3.34 & 1.001 & 0.001 & 207.44 & 0.06 \\
\hline $\mathbf{T}_{7}$ & 68.76 & 1.74 & 2.73 & 4.47 & 1.07 & 0.07 & 307.35 & 4.81 \\
\hline $\mathbf{T}_{8}$ & 63.17 & 1.31 & 2.35 & 3.66 & 1.017 & 0.017 & 231.2 & 1.07 \\
\hline $\mathbf{T}_{9}$ & 63.02 & 1.12 & 2.12 & 3.47 & 1.009 & 0.009 & 213.06 & 0.59 \\
\hline $\mathbf{T}_{10}$ & 62.38 & 1.32 & 2.13 & 3.63 & 1.011 & 0.011 & 226.43 & 0.68 \\
\hline$T_{11}$ & 60.12 & 1.42 & 2.42 & 3.84 & 1.013 & 0.013 & 230.86 & 0.78 \\
\hline$T_{12}$ & 62.14 & 1.21 & 2.25 & 3.46 & 1.014 & 0.014 & 215 & 0.86 \\
\hline Grand Mean & 62.17 & 1.31 & 2.31 & 3.65 & 1.01 & 0.01 & 227.29 & 0.87 \\
\hline S E & 1.88 & 1.52 & 5.82 & 0.76 & 0.81 & 1.42 & 0.12 & 0.02 \\
\hline CD 5\% & 0.65 & 0.52 & 2.01 & 0.26 & 0.28 & NS & 0.04 & 1.34 \\
\hline $\mathrm{CV}$ & 1.40 & 13.29 & 4.91 & 4.68 & 4.48 & 4.09 & 9.32 & 3.97 \\
\hline \multirow[t]{2}{*}{ Range } & \begin{tabular}{l|l} 
Max & 68.76 \\
\end{tabular} & 1.74 & 2.73 & 4.47 & 1.07 & 0.07 & 307.35 & 4.81 \\
\hline & 57.12 & 1.1 & 2.12 & 3.24 & 1.001 & 0.001 & 188.92 & 0.057 \\
\hline
\end{tabular}

The treatment $\mathrm{T}_{0}$ control showed lowest values among all treatments in terms of field emergence $76.10 \%$, plant height $(52.63 \mathrm{~cm})$, number of branches per plant (1.20), days to 50 percent flowering (39.66), number of pods per plant (8.00), number of seeds per pod (5.52), pod fresh weight (1.56 g), pod dry weight $(0.21 \mathrm{~g})$, seed yield per plant $(78.21$ $\mathrm{g})$, biological yield (276.03 g) and harvest index $(1.23 \mathrm{~g})$.

Similar results was reported by Sarika et al., (2013),reported that chemo priming improved the seed quality and showed improved seedling length, seedling dry weight which in turn improved higher seedling vigour index, germination speed and mean germination time. Seed vigour index length parameter depends on germination percentage, shoot length and root length.
The result from the experiment could be concluded that among all the treatments effect of hydration and dehydration with $\left(\mathrm{CaCl}_{2}\right)$ (3\%) was found to be superior in terms of all quantitative and qualitative parameters.

The present study suggests that hydration and dehydration with $\mathrm{CaCl}_{2}$ and secondly $\mathrm{KNO}_{3}$ treatments may improve rapid and uniform seedling germination-emergence and plant development.

\section{References}

Afrigan, A., Javdani, Z., Jahantab, E., Jahanbin and Bahari, A. A. (2013). The effect of plant hormone gibberellic acid on germination indices Secale montanum in vitro and pot experiments under drought conditions. Annals of Biological Research, 4 (6):1-9. 
Ansari, O., and Zadeh, F. S. (2012). Does Gibberelic acid (GA), Salicylic acid (SA) and Ascorbic acid (ASc) improve Mountain Rye (Secale montanum) seeds germination and seedlings growth under cold stress?, International Research Journal of Applied and Basic Sciences, Vol. 3(8), 1651-1657.

Afzal, I., Basara, S. M. A., Farooq, M., and Nawazi, A. (2006). Alleviation of salinity stress in spring wheat by hormonal priming with ABA, Salicylic Acid and Ascorbic Acid. International journal of Agriculture and Biology, Vol. 8, No. 1, 1560-8530.

Aroubandi, H. (2016). The Effect of Priming Treatment on Yield Components of Pea (Greenaro). International Journal of Institutional \& Industrial Research, Vol. 1, pp.10-14.

Bahrani, A., and Pourreza, J. (2012).Gibberlic Acid and Salicylic Acid effects on seed germination and seedlings growth of Wheat (Triticum aestivum L.) under salt stress condition. World Applied Sciences Journal, 18 (5): 633-641.

Farahbakhsh, H. (2012). Germination and seedling growth in primed and primed seeds of fennel as affected by reduced water potential induced by $\mathrm{NaCl}$. Inter Research Journal of Applied Basic Sciences, 3: 737-44.

Hussein, M. M., Balbaa, L. K., and Gaballah, M. S. (2007). Salicylic Acid and salinity effects on growth of Maize plants. Research Journal of Agriculture and Biological Sciences, 3(4): 321-328.

Jyoti, B., Gaurav, S.S., and Pant, U. (2016).Use of growth regulators as priming agent for improvement of seed vigour in tomato (Lycopersicum esculentum). Journal of Applied and Natural Science, 8 (1): 84- 87.

Laal, N., Mahmodi, T. M., and Khaliliaqdam, N. (2015). Effect of Hydro-priming and Hormonal priming on germination traits of Chickpea cultivars. Biological Forum - An International Journal, 7(1): 1693-1697.

Laal, N., Mahmodi, T. M., and Khaliliaqdam, N. (2015). Effect of Hydro-priming and Hormonal priming on germination traits of Chickpea cultivars. Biological Forum - An International Journal, 7(1): 1693-1697.

Lara, T. S., Lira, J. M. S., Rodrigues, A. C., Rakocevic, M., and Alvarenga, A. A. (2014). Potassium Nitrate Priming Affects the Activity of Nitrate Reductase and Antioxidant Enzymes in Tomato Germination. Journal of Agricultural Science, Vol. 6, No. 2.

Nasiri, Y., Feyzi, P., Javanmard, A. (2014). Effects of Hydro and Hormonal Seed Priming on Seed Germination of Milk Thistle under Saline Stress Condition. Notulae Scientia Biologicae, Vol. 6(3):374-380.

Nawaz, A., Amjad, M., Pervez, M. A., and Afzal, I. (2011). Effect of haloprimingon germination and seedling vigor of tomato. African Journal of Agricultural Research, Vol.6(15), pp.3551-3559.

Sarika, G., Basavaraju, G. V., Bhanuprakash, K., Chaanakeshava, V., Paramesh, R. AndRadha, B. N. (2013). Investigation on seed viability and vigour of aged seed by priming in Frenchbean. Vegetable Science, 40: 169-73.

Shehzad.M., Ayub, M., Ahmad, A. U. H., and Yaseen, M. (2012). Influence of priming techniques on emergence and seedling growth of Forage Sorghum (Sorghum bicolor L.). The Journal of Animal \& Plant Sciences, 22(1), Page: 154-158.

Yarnia, M., and Tabrizi, E. F. M. (2012).Effect of seed priming with different concentration of GA3, IAA and Kinetin on Azarshahr Onion germination and seedling Growth. $J$ 
ournal of Basic and Applied Scientific Research, 2(3) 2657-2661.

Zadehbagheri (2014). Salicylic acid priming in corn (Zea mays L. var. Sc.704) reinforce $\mathrm{NaCl}$ tolerance at germination and the seedling growth stage. International Journal of Biosciences, Vol. 4, No. 5, pp. 187-197.

\section{How to cite this article:}

Nalla Bharath Reddy, B. Prudvi Raj, Bineeta M. Bara, K. Jahnavi and Abdul Wajid, G. 2020. Influence of Different Hydration and Dehydration Techniques on Quality and Yield in fenugreek (Trigonella foenumgraecum L.). Int.J.Curr.Microbiol.App.Sci. 9(12): 167-172. doi: https://doi.org/10.20546/ijcmas.2020.912.023 